\title{
New particle formation infrequently observed in Himalayan foothills - why?
}

\author{
K. Neitola ${ }^{1}$, E. Asmi ${ }^{1}$, M. Komppula ${ }^{2}$, A.-P. Hyvärinen ${ }^{1}$, T. Raatikainen ${ }^{1,3}$, T. S. Panwar ${ }^{4}$, V. P. Sharma ${ }^{4}$, and \\ H. Lihavainen ${ }^{1}$ \\ ${ }^{1}$ Finnish meteorological Institute, Helsinki, Finland \\ ${ }^{2}$ Finnish meteorological Institute, Kuopio, Finland \\ ${ }^{3}$ Georgia Institute of Technology, Atlanta, Georgia, USA \\ ${ }^{4}$ Energy and Resource Institute, New Delhi, India
}

Received: 10 December 2010 - Published in Atmos. Chem. Phys. Discuss.: 29 April 2011

Revised: 29 July 2011 - Accepted: 16 August 2011 - Published: 19 August 2011

\begin{abstract}
A fraction of the Himalayan aerosols originate from secondary sources, which are currently poorly quantified. To clarify the climatic importance of regional secondary particle formation in the Himalayas, data from 2005 to 2010 of continuous aerosol measurements at a highaltitude $(2180 \mathrm{~m})$ Indian Himalayan site, Mukteshwar, were analyzed. For this period, the days were classified, and the particle formation and growth rates were calculated for clear new particle formation (NPF) event days. The NPF events showed a pronounced seasonal cycle. The frequency of the events peaked in spring, when the ratio between event and non-event days was $53 \%$, whereas the events were truly sporadic on any other seasons. The annual mean particle formation and growth rates were $0.40 \mathrm{~cm}^{-3} \mathrm{~s}^{-1}$ and $2.43 \mathrm{~nm} \mathrm{~h}^{-1}$, respectively. The clear annual cycle was found to be mainly controlled by the seasonal evolution of the Planetary Boundary Layer (PBL) height together with local meteorological conditions. Spring NPF events were connected with increased PBL height, and therefore characterised as boundary layer events, while the rare events in other seasons represented lower free tropospheric particle formation. This provides insight on the vertical extent of NPF in the atmosphere.
\end{abstract}

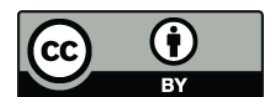

Correspondence to: K. Neitola (kimmo.neitola@fmi.fi)

\section{Introduction}

Secondary particle formation from gaseous precursors is largely recognised as an important worldwide mechanism increasing the number of atmospheric particles (Kulmala et al., 2004; Spracklen et al., 2006, 2009). While in the atmosphere, these particles are affected by several physical and chemical processes influencing the particle climatic properties, such as their scattering and absorbing characteristics and their ability to act as Cloud Condensation Nuclei (CCN). Recent studies have suggested that these particles of secondary origin make a significant addition to the number of climatically relevant particles (Lihavainen et al., 2003; Merikanto et al, 2009, 2010).

Though there is consensus of the importance of secondary particle formation for the global climate, the exact mechanism of particle formation or the chemical compounds involved are not yet truly solved. Compounds participating in nucleation are not known completely, for example ammonia (Ball et al., 1999) and organic compounds (Bonn et al., 2008; Metzger et al., 2010) might act on nucleation. Sulphuric acid is shown to play a key role in atmospheric particle formation (Kulmala et al., 2006; Sipilä et al., 2010; Brus et al.,2010) and ions have been shown to lower the thermodynamic potential of nucleation (Arnold, 1980; Winkler et al., 2008). The role of ions have been deduced to be minor in the boundary layer (Manninen et al., 2010) while increasing the effect in non-polluted environments (Manninen et al., 2010) and in the free troposphere (Lee et al., 2003; Lovejoy et al., 2004).

Due to the uncertainties in the atmospheric particle formation mechanism in different environments, its source

Published by Copernicus Publications on behalf of the European Geosciences Union. 
contribution to the total particle number is difficult to estimate, as was demonstrated e.g. by Makkonen et al., (2009). This creates uncertainties for calculating the climate sensitivity, further associated with quantitative estimates of climate forcing.

The source strength of secondary particle formation and dynamics of the latter growth, as estimated on measurements, have been globally shown to exhibit large site dependent differences (Kulmala et al., 2004). Model results have suggested that approximately $10-48 \%$ of the total particle number in the Planetary Boundary Layer (PBL) (Merikanto et al., 2009, 2010) and up to $41 \%$ in the free troposphere (Merikanto et al., 2009, 2010) are formed via the secondary route. However, even higher estimates have been suggested by different modelling studies, for example Spracklen et al. (2006) report results of about $77.5 \%$ of particles produced via secondary route in PBL while Yu and Luo (2009) report 50-80 \% secondary particles produced in PBL in South and East Asia and even $90 \%$ at higher altitudes. As evident from the scattering of these estimates, it is not well known at which layers of the atmosphere the new particle formation takes place most efficiently. Long-term measurements of particle formation have mainly concentrated on low altitude sites with the best coverage around Europe and northAmerica (Kulmala et al., 2004). Those studies conducted at high altitude sites though, suggest that new particle formation takes place efficiently in the free troposphere (e.g. Clarke et al., 1998; Weber et al., 2001b; Twohy et al., 2002; Venzac et al., 2008).

The high aerosol load in Asian region necessitates dramatic global and local impacts, for example through changing precipitation cycles. Especially the region of Himalayas is highly sensitive to changing aerosol concentration and composition due to the strong regional climate feedbacks. One of the concerns relates to the melting of the snow cover at the Himalayan region (Immerzeel et al., 2009; Krinner et al., 2006; Zhang et al., 2003; Xu et al., 2009) and additional effects on human health are also well recognised (Pandey et al., 2005; Zhang et al., 2007; Liu et al., 2009; Carmichael et al., 2009). Recently, more research has been directed towards understanding Asian aerosols particularly related to the "brown cloud" detected in Southern and Eastern parts (Lelieveld et al., 2001; Nakajima et al., 2007; Ramanathan et al., 2007a, b). This can be seen as several field campaigns (INDOEX, ACE-Asia, TRACE-P, APEX, PEACE, EAREX and APMAX (Ramanathan et al., 2001; Huebert et al., 2003; Jacob et al., 2003; Nakajima et al., 2003; Kondo et al., 2004; Nakajima et al., 2007; Takami et al., 2007) conducted on this area. Some results from short term campaigns have also been reported from the background areas of Himalayas (Sagar et al., 2004; Pant et al., 2006; Dumka et al., 2007; Hegde et al., 2007) but long-term measurements of aerosol particles have been lacking. However, comprehensive long-term measurements are crucial when estimating the effects of aerosols on the global and regional climate. Recently there have also been attempts to establish long-term measurement stations in countries in this area (Carrico et al., 2003; Gajananda et al., 2005; Ramanathan et al., 2007; Bonasoni et al., 2008).

The 2006 inaugurated long-term measurement station in background, high-altitude region in India was initiated by the Finnish Meteorological Institute (FMI) together with The Energy and Resources Institute (TERI), India (Hyvärinen et al., 2009). The station provides a broad range of microphysical and optical measurements of aerosol particle properties, such as the number size distributions of particles (Komppula et al., 2009). In this study we will use four years period of data to quantify the characteristics and seasonal pattern of new particle formation (NPF) events observed at the station. Further emphasis is placed on defining the precursors facilitating new particle formation, as well as on identifying the factors possibly inhibiting the process. Our specific aims are to (1) obtain knowledge on the strength of the secondary particle formation as a source of new particles, and (2) understand which factors are controlling new particle formation at this high altitude region.

\section{Methods}

\subsection{Site description and local meteorology}

The measurements were conducted in Mukteshwar $\left(29^{\circ} 26^{\prime} \mathrm{N}, 79^{\circ} 73^{\prime} \mathrm{E}\right)$ in northeast of India, close to the Nepalese border (Fig. 1). The site is at an altitude of $2180 \mathrm{~m}$ above sea level (a.s.l.) close to the top of the hill in rural region at the Himalaya Mountains. There is a valley down the hill approximately at $500 \mathrm{~m}$ to $1000 \mathrm{~m}$ a.s.l. The closest megacity is New Delhi, located $350 \mathrm{~km}$ southwest from the site. Nearby area has an agricultural test field and the nearest towns are about $25 \mathrm{~km}$ away. Therefore, the influences of local pollution sources are minor. This location can be considered as one of the most remote areas in India and thereby, representative of the regional background in the Indian atmosphere (Komppula et al., 2009). Full description of the site can be found from Hyvärinen et al. (2009).

The local meteorological and climatic conditions follow a strong seasonal cycle. In winter, the temperature can occasionally decrease below zero degrees but snowfall is still rare. Winter is followed by dry and warm spring which is interrupted by the monsoon period, starting approximately in the beginning of July. The autumn meteorological conditions resemble those of the spring, however, with reduced amount of radiation and decreased temperatures (Hyvärinen et al., 2009, Komppula et al., 2009). Following these meteorological boundaries, the seasons were defined as follows: winter (December-February), spring (March-June), monsoon (15 July-15 September) and autumn (16 SeptemberNovember) and are marked as vertical lines in Fig. 2. 


\subsection{On-site measurements}

The on-site measured dataset used here ranges from late November 2005 to late January 2010. The analysis largely relies on the particle number size distributions, measured with a DMPS (Differential Mobility Particle Sizer). The DMPS measured the dry particle size distribution in the size range from 10 to $800 \mathrm{~nm}$, which comprised of 30 discrete size bins measured over a full cycle length of five and a half minutes. The DMPS consisted of a 28 -cm long Viennatype (Winklemayr et al., 1991) Differential Mobility Analyzer (DMA) followed by a Condensation Particle Counter (CPC, TSI model 3010). Before entering the DMA the particles were neutralised with a radioactive bipolar charger (Ni63, $370 \mathrm{MBq}$ ). The DMA was operated in a closed loop arrangement (Jokinen and Mäkelä, 1997) with a critical orifice. The flow rates were set to $5.9 \mathrm{~L} \mathrm{~min}^{-1}$ and $1 \mathrm{~L} \mathrm{~min}^{-1}$ for sheath flow and sample flow, respectively. The relative humidities of both flows were kept low $(<25 \%)$ by using silica gel dryer in the sheath flow and a nafion dryer in the sample flow prior neutralizer. The temperature, pressure and relative humidity of the sheath flow were measured continuously. The measured flow rates and temperatures were used to calculate the particle diffusional losses at different parts of the system (tubes, DMAs, charger, dryer). The diffusional losses together with the calibrated CPC detection efficiency and the particle charging efficiencies as suggested by Wiedensohler, (1988) were used in the routine data inversion.

The DMPS was operated in the main sampling line with a cut-size of $2.5 \mu \mathrm{m}$. Additionally, a wide range of different aerosol properties including total particle number concentrations, $\mathrm{PM}_{2.5}$ and $\mathrm{PM}_{10}$ concentrations, and aerosol scattering and absorption properties were measured at the station. Complete description of the measurements at the site is presented by Hyvärinen et al. (2009). The main meteorological parameters; pressure, relative humidity, temperature, and wind speed together with direction were also measured at the station.

\subsection{Boundary layer evolution and trajectory modelling}

Diurnal evolution of the Planetary Boundary Layer (PBL) height at the station was determined from the European Centre for Medium-Range Weather Forecasts (ECMWF) model that runs with 3-h intervals. The PBL heights were calculated as a distance weighted averages from the four closest integer coordinate points, i.e. one degree resolution.

To gather information on the origin of the air masses and thus on the potential particle sources, the air mass backward trajectories were calculated using a FLEXTRA kinematic trajectory model (Stohl et al., 1995). The trajectories starting every three hours were calculated at the arrival pressure level of $750 \mathrm{hPa}$ and followed $120 \mathrm{~h}$ backwards.

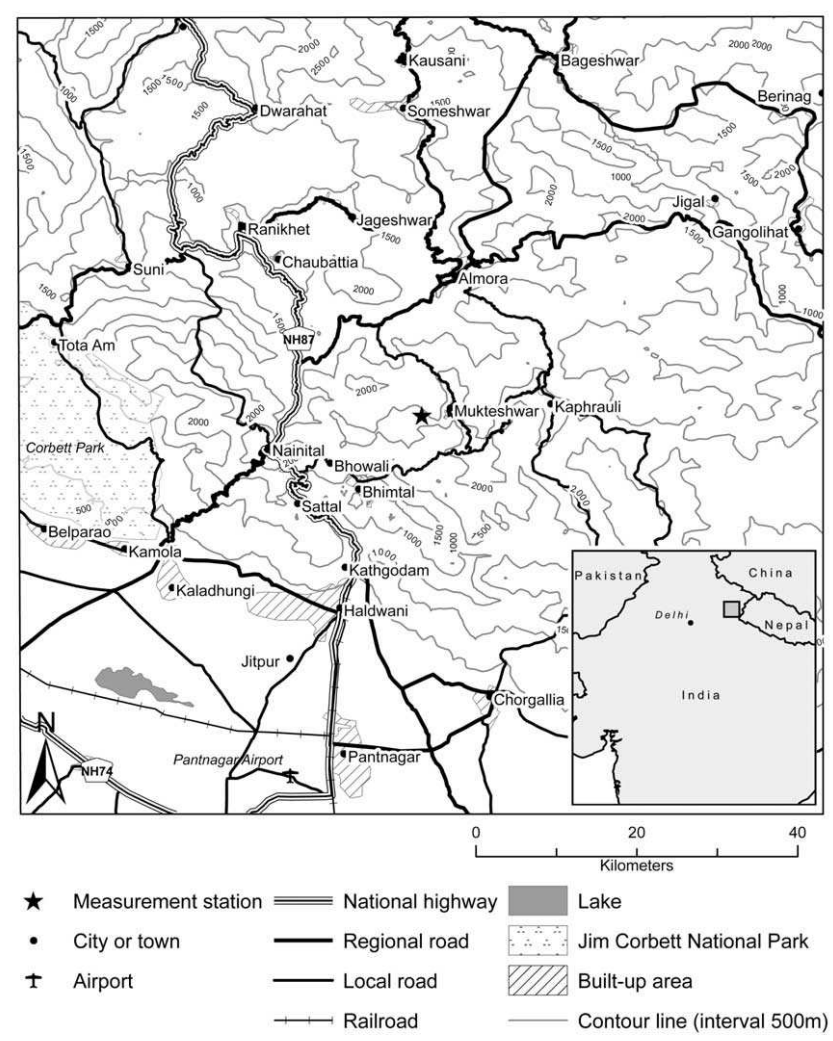

Fig. 1. Location of Mukteshwar measurement site with nearest towns and some terrain properties.

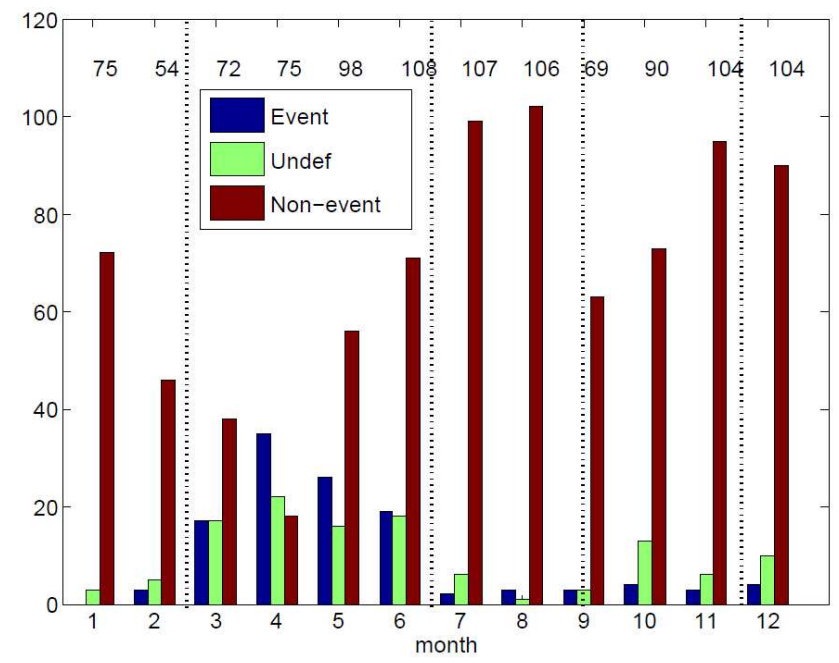

Fig. 2. Number of event, undefined and non-event days in each month for the four year period of time. The number of days with valid data is shown at the top of the figure for each month. The division for seasons (spring: March-June, monsoon: July-15 September, autumn: 16 September-November, winter: DecemberFebruary) are shown as vertical lines. 


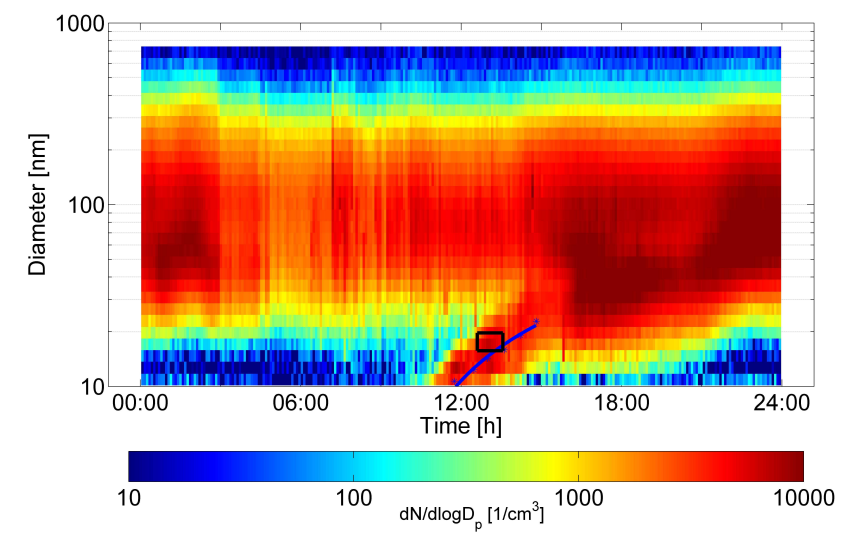

Fig. 3. Particle formation event observed on 26 May, 2009. The blue line shows the fitting of growth rate on the data. The $15 \mathrm{~nm}$ particle formation rate, $J_{15}$, was calculated based on data surrounded by the black box.

\subsection{Analysis of the particle formation characteristics}

The DMPS data was carefully cleaned from any rare contaminations. The size range was divided into three representative fractions recalling atmospheric particle modes: nucleation mode $(<25 \mathrm{~nm})$, Aitken mode $(25-90 \mathrm{~nm})$ and accumulation mode ( $>90 \mathrm{~nm}$ ), following that in Komppula et al. (2009) for the same site.

\subsection{1 lassification of new particle formation events}

Classification of the NPF events followed the procedure presented by Mäkelä et al. (2000) and Dal Maso et al. (2005) and will not be described here thoroughly but the main concept will be presented. The whole 4-yr dataset was visually analysed on day-to-day basis using the measured plotted particle size distributions (see Fig. 3). When a sudden appearance of the nucleation mode particles was followed by the particle growth towards the bigger sizes, the day was classified as an event day. These days were further divided into two different classes, as presented below. Non-event and unclear days were also classified for analysis reasons. The criteria set for each of the four classes are:

- Class I: Clear NPF event with quantitative growth rate (GR) and formation rate (FR)

- Class II: NPF event but not possible to accurately calculate GR and FR, i.e. possible concentration fluctuations during growth or growth was suppressed

- Class III: Undefined, did not fulfil the characteristics of the event nor non-event day, for example no clear growth or growing Aitken mode sized particles

- Class IV: non-event, no nucleation mode particles
The classification was done independently by two researchers and the results were compared afterwards. The rare occasions when those two deviated were re-examined thoroughly until a consensus was reached.

\subsubsection{Growth rate (GR) and apparent formation rate (FR)}

Particle growth rates (GR) were determined by a visual fitting method, similar to that recently used e.g. by Kulmala et al. (2001) and Hamed et al. (2007). The growth rates were assumed constant, thus enabling a linear fit on the visually determined nucleation mode peak diameters as a function of time. An example of the fitting is given in Fig. 3. For five randomly chosen event days, the growth rates were additionally determined by fitting log-normal modes on each of the measured nucleation mode size distributions and by making a linear fit on the obtained mode median diameters, thereby following the method used by Dal Maso et al. (2005). The differences in the obtained growth rates from the two methods were minor.

The rates at which new particles were formed (FR) were calculated at $15 \mathrm{~nm}$ size instead of the lowest measured $10 \mathrm{~nm}$ size mainly for two reasons: (1) Precision of the measurement at $10 \mathrm{~nm}$ is decreased due to diffusional losses and inaccuracy of the power supply at low voltages, and (2) Occasionally the events were observed only after the particles had already reached a size, larger than $10 \mathrm{~nm}$. The second aspect was deduced to be connected with the daily boundary layer evolution and will be discussed in detail later on. The determined $15 \mathrm{~nm}$ particle formation rate should not be mixed with the formation rate of initial critically sized clusters and should therefore be understood as the apparent particle formation rate, emphasising the fact that it is determined as appeared in the measurements after the particles were affected by coagulation and other processes for several hours in the atmosphere.

Formation rate of $15 \mathrm{~nm}$ particles, $J_{15}$, was calculated as

$J_{15}=\frac{d N_{15-20}}{d t}+\operatorname{Coag}_{17} N_{15-20}+\frac{N_{15-20}}{5 \mathrm{~nm}} \mathrm{GR}_{15-20}$,

where the first term describes the temporal change in 15$20 \mathrm{~nm}$ particle number concentration $N$, resulting from particle formation. The second term in Eq. (1) accounts for the losses due to coagulation with bigger particles, where the coagulation sink, CoagS, was calculated similarly as in Kulmala et al. (2001). The particle wet sizes were approximated using the parameterization of the particle hygroscopicity suggested by Laakso et al. (2004), which is developed for boreal forest conditions. The differences in the chemical composition of the Himalayan and boreal forest aerosol then become possible sources of error though according to Wake et al. (1994) the chemical composition of the particles sampled in Eastern Himalayas is mainly ammonia, sulphates and other substances that are commonly found also in boreal forest and the main difference would be expected in the organic 
fraction. However, the growth rates reported in Hirsikko et al. (2005) for boreal forest are in the same range with this study, which gives confidence for the usage of the parameterization by Laakso et al. (2004) also here. The third term in Eq. (1) takes into account the condensational growth of the particles over the upper $20 \mathrm{~nm}$ limit of the size range and uses the growth rates, GR, determined with the above presented methods. On average, for all the analyzed class I nucleation events, the contributions of first, second and third terms were $58 \%, 11 \%$ and $31 \%$, respectively.

An example of class I nucleation event with a fitted particle growth rate is presented in Fig. 3. A box is added on the figure to demonstrate the period for determining the particle formation rate. Noteworthy is, that for the Eq. (1) to apply, the particles need constantly be growing into and out from the studied $15-20 \mathrm{~nm}$ size range. Additionally, only a positive time derivative of the 15-20 nm particle number concentration (1st term in Eq. 1) was calculated. These limitations set the duration of the event and therefore, the width of the box in Fig. 3.

\section{Results}

\subsection{Event characteristics}

\subsubsection{Seasonal cycle}

Our dataset contained 1519 days of which 1062 days were classifiable. Rest of the days contained missing or bad data. Total of 119 events were found which corresponds to $11.2 \%$ of the classified days. There were 823 non-event days (77.5\% of classified days) and the rest were defined as undefined (11.3\% of classified days). The overall event to nonevent ratio was $14.5 \%$.

The annual cycle of new particle formation events was pronounced (Fig. 2). The events were the most frequent on spring months (March-June) when altogether 97 event days, equating $81.5 \%$ of the events, were observed. In contrast during summer (July-15 September) only 5 event days, equating $4.2 \%$ of the events were detected. The number of non-event days had an inverse annual cycle as compared to the number of events, thus having the lowest values on spring and highest on summer. The annual cycle of undefined days resembled to that of the events. This is at least by part explained by occasionally suppressed or interrupted particle growth.

\subsection{Particle formation and growth rates}

The mean particle growth rate as calculated from the whole data set was $2.43 \mathrm{~nm} \mathrm{~h}^{-1}$ with the largest mean values during winter $\left(3.1 \mathrm{~nm} \mathrm{~h}^{-1}\right)$ and spring $\left(2.47 \mathrm{~nm} \mathrm{~h}^{-1}\right)$ seasons. The lowest growth rates were found during autumn with a mean value of $1.43 \mathrm{~nm} \mathrm{~h}^{-1}$. The mean growth rates and their quartiles for different seasons are presented in Fig. 4.

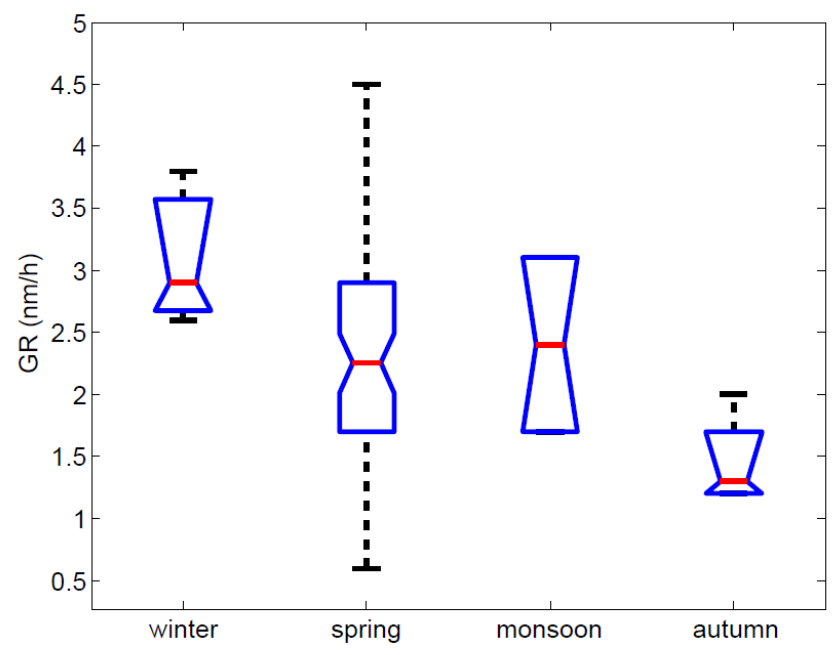

Fig. 4. Seasonal averaged particle growth rates (GR) with quartiles. Red lines indicate median values, upper and lower lines of the box present the 25 th and 75 th percentiles and the black lines indicate the extent of the data.

The overall mean $15 \mathrm{~nm}$ particle formation rate was $0.4 \mathrm{~cm}^{-3} \mathrm{~s}^{-1}$ varying from $0.14 \mathrm{~cm}^{-3} \mathrm{~s}^{-1}$ (autumn) to $0.44 \mathrm{~cm}^{-3} \mathrm{~s}^{-1}$ (spring) between seasonal mean values. Table 1 presents the seasonal mean particle growth and formation rates. However, it should be noticed that due to the strong seasonality of the occurrence of the events, the statistics remain rather poor for any other season than spring.

\subsection{Factors affecting the particle formation characteristics}

\subsubsection{Local meteorology}

Meteorological conditions can favour or suppress particle formation. Higher solar radiation promotes the photochemical oxidation processes, for example, through increasing the number of $\mathrm{OH}$ radicals. Radiation also increases the vertical mixing of the atmosphere diluting the condensation sink (CS, see e.g. Kulmala et al., 2001). Increased relative humidity has been linked with suppressed nucleation due to the wet scavenging of particles and precursor gases and increased CS by growing particles (Hamed et al., 2007).

The seasonal mean values of meteorological parameters are presented in Table 2. Most of the detected NPF events $(81.5 \%)$ occurred during spring season. Indeed, the meteorological conditions during spring were favourable for particle formation (Table 2). The global radiation was the most intense during the spring (mean value of $203.4 \mathrm{~W} \mathrm{~m}^{-2}$ ). Spring was also relatively dry allowing the particles and the precursor gases to be not scavenged by wet deposition and inhibiting the CS to increase by the particle hygroscopic growth.

In contrast, the lack of the events during monsoon season was most likely reasoned by the nearly sustained rain that 
Table 1. Seasonal and total averaged particle growth and formation rates.

\begin{tabular}{llllll}
\hline & winter & spring & monsoon & autumn & total \\
\hline Growth rate $\left(\mathrm{nm} \mathrm{h}^{-1}\right)$ & 3.10 & 2.47 & 2.40 & 1.45 & 2.43 \\
Formation rate $\left(\mathrm{cm}^{-3} \mathrm{~s}^{-1}\right)$ & 0.20 & 0.44 & 0.25 & 0.14 & 0.40 \\
\hline
\end{tabular}

Table 2. Seasonal averaged meteorological conditions.

\begin{tabular}{lllll}
\hline & Winter & Spring & Monsoon & Autumn \\
\hline Relative humidity $(\%)$ & 37.6 & 54.6 & 87.2 & 63.7 \\
Temperature $\left({ }^{\circ} \mathrm{C}\right)$ & 9.6 & 16.4 & 17.8 & 13.6 \\
Global irradiance $\left(\mathrm{W} \mathrm{m}^{-2}\right)$ & 138.2 & 203.4 & 136.7 & 177.0 \\
\hline
\end{tabular}

effectively removes the particles and precursor gases, such as $\mathrm{SO}_{2}$, below the cloud base. Also the lack of direct sun light near the ground layer reduces the photochemistry and thereby, the formation of sulphuric acid molecules via the oxidation of $\mathrm{SO}_{2}$ by ozone and $\mathrm{OH}$ molecules.

Why particle formation was not regularly observed during autumn and winter becomes, however, not evident by comparing the seasonal meteorological conditions. Reduced radiation during winter might cause a lack of oxidation reagents together with reduced vertical mixing of the lower atmosphere (increased CS) thereby causing depletion of precursor gases. In autumn the amount of radiation was as well slightly decreased as compared with the spring, and the temperature was somewhat lower. Yet, the dramatic NPF seasonal cycle would be unlikely to be explained by such small deviations in meteorological conditions.

\subsubsection{Origin of the air masses}

The air mass back trajectories were studied to reveal possible correlations between the NPF events and specific source regions. Figure 5 shows the average direction of the trajectories calculated 120-h backwards separately for the event and non-event days during spring and other seasons. The other seasons were bundled with statistical reasons and covered altogether 22 event days, whereas the spring season covered 97 event days. Trajectories from west (region between $240^{\circ}$ and $300^{\circ}$ ) were found to be characteristic for spring time NPF events. West is also the prevailing wind direction during the whole year, except for the monsoon season (Hyvärinen et al., 2009). Relatively common in spring were also the air masses originating from the Nepalese mountain region in south-east $\left(120-150^{\circ}\right)$ but NPF events were not commonly seen within these air masses. For the rest of the year (other seasons) the occurrence of the NPF events was not connected with any specific air mass origin, but sporadic events were observed regardless of the direction.
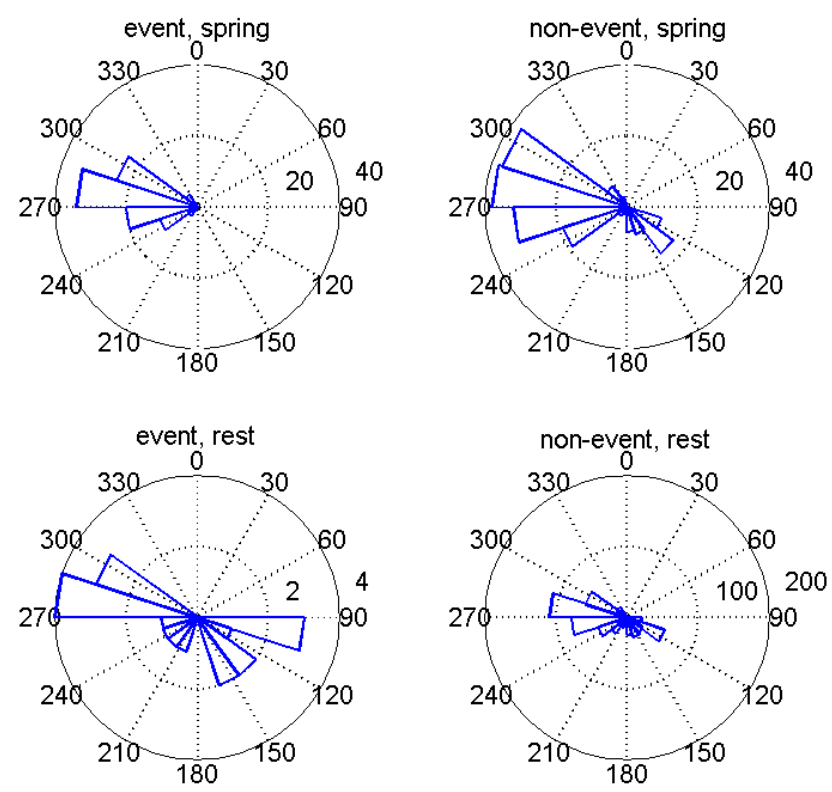

Fig. 5. The incoming trajectory directions in degrees for event and non-event days divided in to spring and other seasons. Trajectories are calculated $120 \mathrm{~h}$ backwards.

The height of the trajectory paths was also studied but no firm effect on the NPF could be found. The mean height for the path of the incoming trajectories was $2461 \mathrm{~m}$ a.g.l. ( $3212 \mathrm{~m}$ a.s.l.) on the event days in contrast to $2439 \mathrm{~m}$ a.g.l. ( $3169 \mathrm{~m}$ a.s.1.) on the non-event days as calculated using arrival times between 11:30 a.m. and 2:30 p.m. when NPF events were mainly observed.

\subsubsection{Boundary layer evolution}

The boundary layer height starts to increase after dawn when the rapidly warming surface air becomes uplifted. The top of the boundary layer could under favourable meteorological conditions reach the altitude of the station 


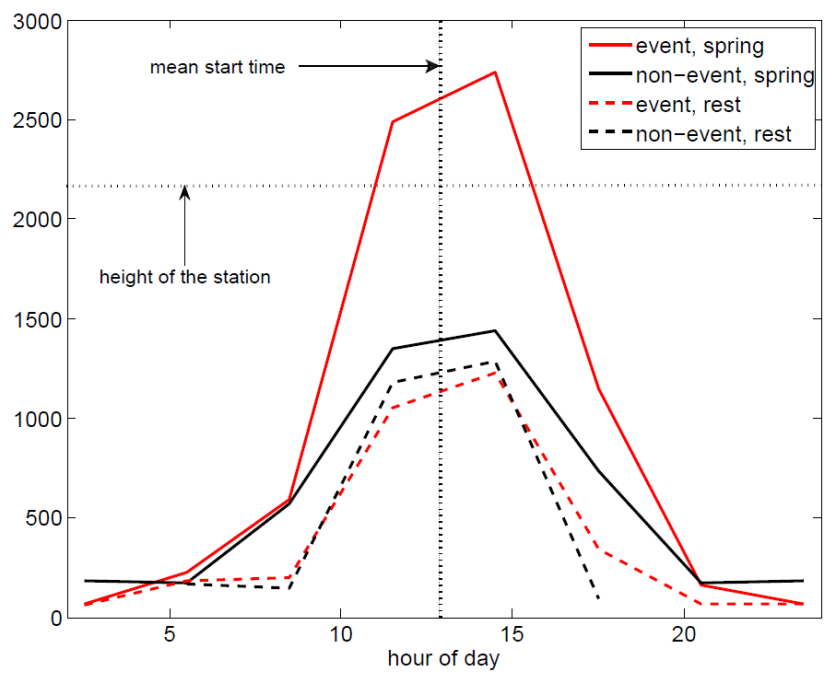

Fig. 6. Comparison between spring and other seasons diurnal variation of the mean boundary layer height for event and non-event days. Vertical line shows the mean starting time of the nucleation events during spring seen at the particle diameter of $15 \mathrm{~nm}$.

(2180 $\mathrm{m}$ a.s.1.), which further enables the transport of particle precursors and local pollution from lower altitudes to the station (Raatikainen et al., 2010). This would be expected to drastically affect the observed NPF. Unfortunately, it is not straightforward to separate between boundary layer (BL) and free tropospheric (FT) air solely based on measured quantities. Here, the modelled PBL heights were used to distinguish between occasions of free tropospheric and boundary layer particle formation.

Figure 6 shows the comparison between spring and other seasons diurnal variation of the boundary layer height for event and non-event days at the Mukteshwar station. The average time for beginning of a formation events during spring was 1:51 p.m. LT and is marked in Fig. 6 as a vertical line. Note that here the start time is defined as the time the NPF is detected at $15 \mathrm{~nm}$, so the initial nucleation start time is considerably earlier. An estimate of the initial nucleation time could be done using GR data from Table 2 but growth rate probably does not stay constant due to dilution of condensing vapours, changing $\mathrm{CS}$ etc. during rising of the boundary layer. A clear difference in the evolution of the boundary layer between spring and other seasons during NPF event and non-event days is evident. The uplift of the warm air appears to be significantly more efficient during the spring season, when the global radiation is enhanced. In spring, NPFs are connected with very high boundary layer height, reaching the station altitude level prior to the observed particle formation. The mean value of the boundary layer height during spring at the event start time was about $2600 \mathrm{~m}$ a.s.l. In contrast, on non-event days in spring the mean PBL height stayed well below the altitude of the station during the whole day. Figure 7 shows the number of event and non-event days as a

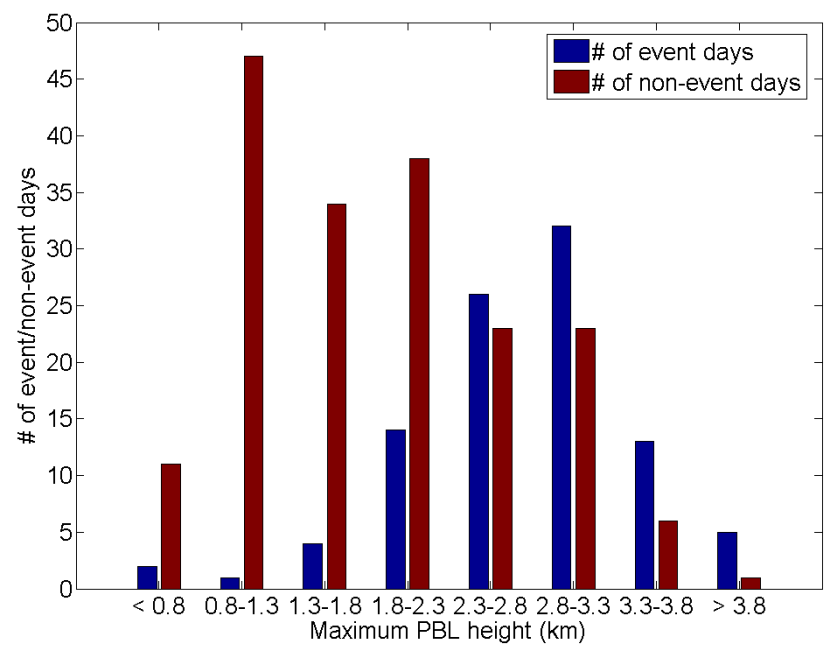

Fig. 7. Number of event (blue) and non-event (red) days in each interval of maximum PBL height during spring season.

function of maximum PBL height during spring. Within the uncertainty rising from the PBL model, most of the events occur when the top of the boundary layer is reaching the station altitude. However, the PBL reaching the station does not solely necessitate a NPF event as also seen from Fig. 7.

During other seasons, no difference in the boundary layer evolution between event and non-event days was detected and the mean PBL reached only $1200 \mathrm{~m}$ a.s.l. on both the event and non-event days (Fig. 6). This is well below the station altitude and therefore, the rare nucleation events observed at the station on other seasons could be considered as free tropospheric particle formation.

\subsubsection{Sinks of vapours and particles}

A high background particle concentration can hinder particle nucleation and growth since particles act as a sink for both; vapours and the initially formed nm-sized particles. Average $\mathrm{PM}_{2.5}$ concentration, representative of this background sink, for different seasons is presented in Fig. 8 for event, undefined and non-event days, as calculated between noon and 2 p.m. This time window was chosen to correspond to the times of observed particle formation. Using the $\mathrm{PM}_{2.5}$ concentration calculated at the time when the NPF event started would probably underestimate the CS because the rising boundary layer increases the $\mathrm{PM}_{2.5}$ concentration and calculated values would be taken from free tropospheric conditions. The air masses that are uplifted to the station are assumed to be the most representative of the $\mathrm{PM}_{2.5}$ concentration at the time when NPF event started due to the fact that they are measured in the same air mass as the particles are formed. During monsoon and autumn seasons, the average $\mathrm{PM}_{2.5}$ concentrations on event days were only about half or less of the concentration on the non-event days. Therefore it seems that indeed, during summer and autumn, the 


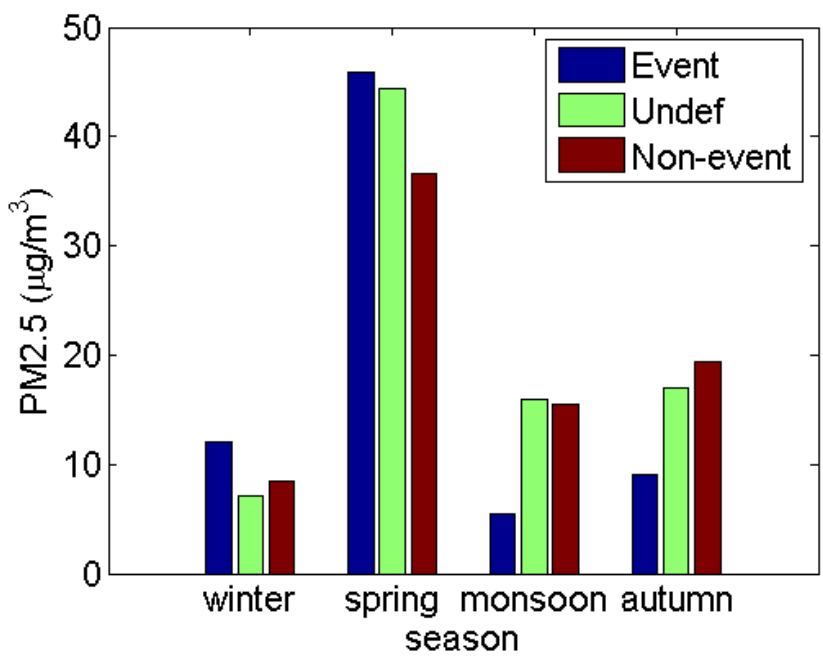

Fig. 8. $\mathrm{PM}_{2.5}$ concentration between noon and 2 p.m. for event, undefined and non-event days and separately for different seasons.

Table 3. Seasonal average condensation sink (CS) on NPF event days and non-event days between noon and 2 p.m.

\begin{tabular}{lllll}
\hline & winter & spring & monsoon & autumn \\
\hline NPF event $\left(10^{-3} \mathrm{~s}^{-1}\right)$ & 5.7 & 14.7 & 3.9 & 5.1 \\
Non-event $\left(10^{-3} \mathrm{~s}^{-1}\right)$ & 8.3 & 15.6 & 6.5 & 9.8 \\
\hline
\end{tabular}

lack of the nucleating and condensing vapours can be a factor inhibiting particle formation. In spring contrary is true, and the background $\mathrm{PM}_{2.5}$ mass concentration is larger for event days $\left(46 \mu \mathrm{g} \mathrm{m}^{-3}\right)$ than for undefined $\left(44 \mu \mathrm{g} \mathrm{m}^{-3}\right)$ and non-event days $\left(35 \mu \mathrm{g} \mathrm{m}^{-3}\right)$. This is an indication that NPF events during spring happen in PBL, instead of free troposphere, which seems to be the case on other seasons. The overall average mass concentrations during spring are much higher than during other seasons, evident of the frequent uplifting of the more polluted lower altitude air masses, as follows from the daily evolution of the PBL. However, the enhanced sink for the vapours in spring do not seem to inhibit particle formation but quite opposite, NPF takes frequently place. These polluted air-masses thus seem to contain very high amounts of vapours to enhance particle nucleation and growth. The background mass concentrations during winter do not show consistent decrease nor increase following the NPF, undefined and non-event days, however, the statistics are rather poor due to long periods of missing $\mathrm{PM}_{2.5}$ mass data in winter.

Similar behaviour can be seen from Table 3, where the seasonal averaged CS for event and non-event days are presented. The CS is only slightly lower for event days than for non-event days during spring. This different behaviour of $\mathrm{PM}_{2.5}$ and CS during spring on event and non-event days indicates large particles to contribute more on the mass $\left(\mathrm{PM}_{2.5}\right)$ than on the surface area (CS). On other seasons the CS is significantly lower for event days than for non-event days. This suggests that nucleation on other seasons occur in free tropospheric conditions where nucleating vapour concentrations are lower and thus, smaller CS is necessary for not to deplete the precursor gases. However, this should be interpreted with caution due to the lack of the actual precursor gas measurements.

\section{Discussion}

The strong seasonality in particle formation observed at the high-altitude mainly appeared to manifest the evolution of the planetary boundary layer. The results suggest that secondary particle formation is efficiently producing particles in the planetary boundary layer of the Indian remote background regions where nucleating and condensing vapours are abundant. In contrast, in the meteorological conditions of the lower parts of the free troposphere, the lack of gaseous precursors seems to inhibit frequent secondary particle formation. However, in conditions of low background particle numbers, i.e. small vapour sink, particle formation could take place also right above the planetary boundary layer.

The obtained characteristics of the particle formation events, such as the particle formation and growth rates, are comparable with previous observations in high-altitude sites. For example, Venzac et al. (2008) reported growth rates of $1.8 \pm 0.7 \mathrm{~nm} \mathrm{~h}^{-1}$ in the Nepalese Himalayas at an elevation of $5079 \mathrm{~m}$ a.s.l., thus slightly smaller than found in this study. On contrary Nishita et al. (2008) reported growth rates of $2.6-3.1 \mathrm{~nm} \mathrm{~h}^{-1}$ in Mt. Norikura, Japan at altitude of $2770 \mathrm{~m}$ and Venzac et al. (2009) 4.7-5.6 $\mathrm{nm} \mathrm{h}^{-1}$ in Puy de Dôme, France at an elevation of $1465 \mathrm{~m}$. The growth rates obtained here, fit right on top of the ones from Japan which were measured approximately at the same elevation. These results suggest that increasing altitude results in decreased growth rate. This might be due to the more pronounced dilution of the boundary layer air masses as it rises and mixes with more clean free tropospheric air masses decreasing the amount of condensable vapours. Data on formation rates are reported only by Venzac et al. (2009) from previously mentioned articles, which ranged from $J_{10}=0.14$ to $J_{10}=0.20 \mathrm{~cm}^{-3} \mathrm{~s}^{-1}$ which are at the lower end of the range obtained in this study $\left(J_{15}=0.14\right.$ to $\left.J_{15}=0.44 \mathrm{~cm}^{-3} \mathrm{~s}^{-1}\right)$.

The rate of nucleation events occurring in Mukteshwar is low compared to the values measured in Nepal Climate Observatory at Pyramid (Venzac et al., 2008), where $39.1 \%$ of the days had a NPF event during their 16-month study having maximum rate during the monsoon season. According to Bonasoni et al. (2010) on $80 \%$ of the afternoon hours the Pyramid station was covered with thick clouds during monsoon season and only $10 \%$ of the time the sky was cloudfree. NPF events are unlikely to happen without direct sun shine or during rain due to wet scavenging of precursor gases. 
At Mukteshwar the highest rate was found during spring which indicates different conditions for the particle formation. Events in Mukteshwar occurred almost only when the boundary layer had risen to the altitude of the station bringing vapours from ground level emission that enabled particle formation. At the Pyramid station the events occurred in free troposphere due to the high elevation of the station. This indicates that free tropospheric particle formation is more efficient at higher altitudes, where the sinks for vapours and particles are low and increased irradiance due to low number of clouds are favourable for particle formation, than in lower altitudes represented by Mukteshwar or Mt. Norikura.

\section{Conclusions}

Our results suggest that new particle formation is a less frequent phenomenon in Mukteshwar, an Indian Himalayan high-altitude site. The overall event to non-event ratio, determined from four years of continuous measurements, was only $14.5 \%$.

Surprisingly pronounced annual pattern in the occurrence of the particle formation was observed (Fig. 2). The vast majority of the events were observed on spring months from March till June ( $81.5 \%$ of all events), when the event to nonevent ratio was as high as $53 \%$. Minimum was detected during summer monsoon season, when the ratio was only $2 \%$, possibly affiliated with the unfavourable meteorological conditions, such as low radiation below cloud base and particle wet scavenging. However, also during autumn and winter, the particle formation events were only sporadic.

The particle formation rates $\left(J_{15}\right)$ were the highest during spring, with a mean value of $0.44 \mathrm{~cm}^{-3} \mathrm{~s}^{-1}$. During other seasons the mean formation rates ranged from 0.14 to $0.25 \mathrm{~cm}^{-3} \mathrm{~s}^{-1}$. The mean growth rates varied from $1.45 \mathrm{~nm} \mathrm{~h}^{-1}$ in winter to $3.1 \mathrm{~nm} \mathrm{~h}^{-1}$ in autumn, reflecting the amount of available condensable vapours and the condensation sink. While the condensation sink for the vapours was clearly the highest in spring this suggest that the amount of condensing vapours was higher in spring than in any other season.

The strong seasonality of the events was connected with the planetary boundary layer evolution. The height of the boundary layer was able to exceed the altitude of the measurement site (2180 a.s.l.) mainly during spring, in which case the precursor gases and previously nucleated particles reached the station and an event was observed. Figures 6 and 7 show unambiguously that during spring, the nucleation events only occur when the boundary layer height has reached the altitude of the station. When boundary layer reaches the station the background concentration increases affiliated to the transport of pollution from near-surface emissions. This is clearly seen in Fig. 8 especially on spring, when, during nucleation, background concentrations are the highest. On non-event days the background concentration is lower while the station remains above the top of the boundary layer. However, boundary layer reaching the station does not necessarily correspond to an event due to the variability of the condensation sink (pre-existing particles) and concentration of precursor gases. During spring season NPF events occurred on $59 \%$ of the days when boundary layer reached the altitude of the station. On other seasons than spring, the boundary layer height never exceeded the altitude of the station during NPF event. Thus, the sporadic observations of particle formation on other seasons were deduced to take place in the free troposphere. On the other hand, there are 77 days when PBL reached the height of the station on other seasons than spring and no NPF event was detected. Due to the lack of visibility measurements, it is difficult to speculate on the existence of clouds or rain during these days, which might have inhibited the NPF events. In contrast to PBL spring events, a low pre-existing particle background seemed to promote this free tropospheric particle formation, indicating a lack of nucleating and condensing vapours in higher atmospheric layers.

The trajectories of the air masses coming to the station did not show any clear correlation with the occurrence of nucleation events on most of the seasons. However, during spring, all of the events occurred when trajectories were coming from west (Fig. 5). This is also the prevailing wind direction but the fact that no events were seen with air masses coming from any other direction during spring can indicate precursor sources on the west side area of the station. There are few towns and a national highway on the west side of the station about 20 to $30 \mathrm{~km}$ away.

From these findings the annual cycle in Mukteshwar can be divided in two parts, spring and other seasons when considering only particle formation. During the spring time, nucleation is almost solely boundary layer nucleation where surface emitted precursor gases (e.g. $\mathrm{SO}_{2}, \mathrm{NO}_{x}$ ) are needed to initiate the nucleation. The concentrations of these gases must be considerably higher than, for example, in Hyytiälä (Dal Maso et al., 2005) due to the higher CS. When the background concentration of particles grows, it increases the condensation sink which can explain the large number of undefined days during spring where the growth was interrupted by lack of condensable vapours. Most of the nucleation events during other seasons can be considered as free tropospheric nucleation, considering the boundary layer height (Fig. 6) and the background concentrations (Fig. 8) during the events. Also the trajectory distribution (Fig. 5) has no pattern during event days for other seasons than spring, indicating no connection between the event and nearby surface emissions.

The frequency of particle formation during other seasons is very low and it can be concluded that lower free tropospheric particle formation is only a minor source of particles in Mukteshwar. This is somewhat in contradiction with the proposed idea that nucleation takes place in the entire atmospheric column, which was based on frequently observed NPF at $5079 \mathrm{~m}$ altitude at the ABC-Pyramid Atmospheric 
Research Observatory in Nepal (Venzac et al., 2008). Instead, our observations are similar to those of Crumeyrolle et al. (2010) who observed that the vertical extent of NPF events was limited by the height of the boundary layer. This implies that the vertical structure of NPF occurrence is complicated and more observations are needed especially in the lower and upper free troposphere to constrain the uncertainties in global climate models.

Acknowledgements. This work was financially supported by Maj $\&$ Torr Nessling foundation and the Ministry of foreign affairs of Finland.

Edited by: J. Curtius

\section{References}

Arnold, F.: Multi-ion complexes in the stratosphere-implications for trace gases and aerosol, Nature, 284, 610-611, 1980.

Ball, S. M., Hanson, D. R., Eisele, F. L., and McMurry, P. H.: Laboratory studies of particle nucleation: initial results for $\mathrm{H}_{2} \mathrm{SO}_{4}$, $\mathrm{H}_{2} \mathrm{O}$, and $\mathrm{NH}_{3}$ vapors. J. Geophys. Res., 104, 23709-23718, 1999.

Bonasoni, P., Laj, P., Angelini, F., Arduini, J., Bonafè, U., Calzolari, F., Cristofanelli, P., Decesari, S., Facchini, M. C., Fuzzi, S., Gobbi, G. P., Maione, M., Marinoni, A., Petzold, A., Roccato, F., Roger, J. C., Sellegri, K., Sprenger, M., Venzac, H., Verza, G. P., Villani, P., and Vuillermoz, E.: The ABC-Pyramid Atmospheric Research Observatory in Himalaya for aerosol, ozone and halocarbon measurements, Sci. Total Environ., 391(2-3), 252-261, 2008.

Bonasoni, P., Laj, P., Marinoni, A., Sprenger, M., Angelini, F., Arduini, J., Bonafè, U., Calzolari, F., Colombo, T., Decesari, S., Di Biagio, C., di Sarra, A. G., Evangelisti, F., Duchi, R., Facchini, M. C., Fuzzi, S., Gobbi, G. P., Maione, M., Panday, A., Roccato, F., Sellegri, K., Venzac, H., Verza, G. P., Villani, P., Vuillermoz, E., and Cristofanelli, P.: Atmospheric Brown Clouds in the Himalayas: first two years of continuous observations at the Nepal Climate Observatory-Pyramid (5079 m), Atmos. Chem. Phys., 10, 7515-7531, doi:10.5194/acp-10-7515-2010, 2010.

Bonn, B., Kulmala, M., Riipinen, I., Sihto, S.-L., and Ruuskanen, T. M.: How biogenic terpenes govern the correlation between sulfuric acid concentrations and new particle formation, J. Geophys. Res., 113, D12209, doi:10.1029/2007JD009327, 2008.

Brus, D., Neitola, K., Hyvrinen, A.-P., Petäjä, T., Vanhanen, J., Sipil, M., Paasonen, P., Kulmala, M., and Lihavainen, H.: Homogenous nucleation of sulfuric acid and water at close to atmospherically relevant conditions, Atmos. Chem. Phys., 11, 52775287, doi:10.5194/acp-11-5277-2011, 2011.

Carmichael, G. R., Adhikary, B., Kulkarni, S., D'allura, A., Tang, Y., Streets, D., Zhang, Q., Bond, T. C., Ramanathan, V., Jamreonsan, A., and Marrapu, P.: Asian Aerosols: Current and Year 2030 Distributions and Implications to Human Health and Regional Climate Change, Environ. Sci. Technol., 43, 5811-5817, 2009.

Carrico, C. M., Kus, P., Rood, M. J., Quinn, P. K., and Bates, T. S.: Mixtures of pollution, dust, sea salt, and volcanic aerosol during ACE-Asia: Radiative properties as a function of relative hu- midity, J. Geophys. Res., 108(D23), 8650, doi:10.1016/S13522310(03)00197-3, 2003.

Clarke, A. D., Varner, J. L., Eisele, F., Mauldin, R. L., Tanner, D., and Litchy, M.: Particle production in the remote marine atmosphere: Cloud outflow and subsidence during ACE 1, J. Geophys. Res. D, 103, 16397-16409, 1998.

Crumeyrolle, S., Manninen, H. E., Sellegri, K., Roberts, G., Gomes, L., Kulmala, M., Weigel, R., Laj, P., and Schwarzenboeck, A.: New particle formation events measured on board the ATR-42 aircraft during the EUCAARI campaign, Atmos. Chem. Phys., 10, 6721-6735, doi:10.5194/acp-10-6721-2010, 2010.

Dal Maso M., Kulmala, M., Riipinen, I., Wagner, R., Hussein1, T., Aalto, P. P., and Lehtinen, K. E. J.: Formation and growth of fresh atmospheric aerosols: Eight years of aerosol size distribution from SMEAR II, Hyytiälä, Finland, Boreal Environ. Res., 10, 323-336, 2005.

Dumka, U. C., Satheesh, S. K., Pant, P., Hegde, P., and Moorthy, K. K.: Surface changes in solar irradiance due to aerosols over central Himalayas, Geophys. Res. Lett., 33, L20809, doi:10.1029/2006GL027814, 2006.

Gajananda, K., Kuniyal, J. C., Momin, G. A., Rao, P. S. P., Safai, P. D., Tiwan, S., and Ali, K.: Trend of atmospheric aerosols over the north western Himalayan region, India, Atmos. Environ., 39, 4817-4825, 2005.

Hamed, A., Joutsensaari, J., Mikkonen, S., Sogacheva, L., Dal Maso, M., Kulmala, M., Cavalli, F., Fuzzi, S., Facchini, M. C., Decesari, S., Mircea, M., Lehtinen, K. E. J. and Laaksonen, A.: Nucleation and growth of new particles in Po Valley, Italy, Atmos. Chem. Phys., 7, 355-376, doi:10.5194/acp-7-355-2007, 2007.

Hegde, P. Pant, P., Naja, M. Dumka, U. C., and Sagar, R.: South Asian dust episode in June 2006: Aerosol observations in the central Himalayas, Geophys. Res. Lett., 34, L23802, doi:10.1029/2007GL030692, 2007.

Hirsikko, A., Laakso, L., Hõrrak, U., Aalto, P. P., Kerminen, V.M., and Kulmala, M.: Annual and size dependent variation of growth rates and ion concentrations in boreal forest, Boreal Environ. Res., 10, 357-369, 2005.

Huebert, B. J., Bates, T., Russell, P. B., Shi, G., Kim, Y. J., Kawamura, K., Carmichael G., and Nakajima, T.: An overview of ACE-Asia: Strategies for quantifying the relationships between Asian aerosols and their climatic impacts, J. Geophys. Res., 108(D23), 8633, doi:10.1029/2003JD003550, 2003.

Hyvärinen, A. P., Lihavainen, H., Komppula, M., Sharma, V. P., Kerminen, V.-M., Panwar, T. S., and Viisanen, Y.: Continuous measurements of optical properties of atmospheric aerosols in Mukteshwar, northern India, J. Geophys. Res., 114, D08207, doi:10.1029/2008JD011489, 2009.

Immerzeel, W. W., Droogers, P., de Jong, S. M., and Bierkens, M. P. F.: Large-scale monitoring of snow cover and runoff simulation in Himalayan river basins using remote sensing, Remote Sens. Environ., 113, 40-49, 2009.

Jacob, D. J., Crawford, J. H., Kleb, M. M., Connors, V. S., Bendura, R. J., Raper, J. L., Sachse, G. W., Gille, J. C., Emmons, L., and Heald, C. L.: The Transport and Chemical Evolution over the Pacific (TRACE-P) aircraft mission: Design, execution, and first results, J. Geophys. Res., 108(D20), 8781, doi:10.1029/2002JD003276, 2003.

Jokinen, V. and Mäkelä, J. M.: Closed-loop arrangement with criti- 
cal orifice for DMA sheath/ excess flow system. J. Aerosol Sci., 28, 643-648, 1997.

Komppula, M., Lihavainen, H., Hyvärinen, A.-P., Kerminen, V.-M., Panwar, T. S., Sharma, V. P., and Viisanen, Y.: Physical properties of aerosol particles at a Himalayan background site in India, J. Geophys. Res., 114, D12202, doi:10.1029/2008JD011007, 2009.

Kondo, Y., Nakamura, K., Chen, G., Takegawa, N., Koike, M., Miyazaki, Y., Kita, K., Crawford, J., Ko, M., Blake, D. R., Kawakami, S., Shirai, T., Liley, B., Wang, Y., and Ogawa, T.: Photochemistry of ozone over the western Pacific from winter to spring, J. Geophys. Res., 109, D23S02, doi:10.1029/2004JD004871, 2004.

Krinner, G., Boucher, O., and Balkanski, Y.: Ice-free glacial northern Asia due to dust deposition on snow, Clim. Dynam., 27, 613625, 2006.

Kulmala, M., Dal Maso, M., Mäkelä, J. M., Pirjola, L., Väkevä, M., Aalto, P., Miikkulainen, P., Hämeri, K., and O'Dowd, C.: On the formation, growth, and composition of nucleation mode particles, Tellus, 53B, 479-490, 2001.

Kulmala, M., Vehkamäki, H., Petäjä, T., Dal Maso, M., Lauri, A., Kerminen, V.-M., Birmili, W., and McMurry, P. H.: Formation and growth rates of ultrafine atmospheric particles: A review of observations, J. Aerosol Sci., 35, 143-176, 2004.

Kulmala, M., Lehtinen, K. E. J., and Laaksonen, A.: Cluster activation theory as an explanation of the linear dependence between formation rate of $3 \mathrm{~nm}$ particles and sulphuric acid concentration, Atmos. Chem. Phys., 6, 787-793, doi:10.5194/acp-6-787-2006, 2006.

Laakso L., Petäjä T., Lehtinen K., Kulmala M., Paatero J., Hõrrak U., Tammet H. and Joutsensaari J. 2004. Ion production rate in a boreal forest based on ion, particle and radiation measurements. Atmos. Chem. Phys., 4, 1933-1943, doi:10.5194/acp-4-19332004, 2004.

Lee, S.-H., Reeves, J. M., Wilson, J. C., Hunton, D. E., Viggiano, A. A.,Miller, T. M., Ballenthin, J. O., and Lait, L. R.: Particle Formation by Ion Nucleation in the Upper Troposphere and Lower Stratosphere, Science, 301, 5641, 1886-1889, 2003.

Lelieveld, J., Crutzen, P. J., Ramanathan, V., Andreae, M. O., Brenninkmeijer, C. A. M., Campos, T., Cass, G. R., Dickerson, R. R., Fischer, H., de Gouw, J. A., Hansel, A., Jefferson, A., Kley, D., de Laat A. T. J., Lal S., Lawrence, M. G., Lobert, J. M., MayolBracero, O., Mitra, A. P., Novakov, T., Oltmans, S. J., Prather, K. A., Reiner, T., Rodhe, H., Scheeren, H. A., Sikka, D., and Williams, J.: The Indian Ocean Experiment: Widespread air pollution from South and Southeast Asia, Science, 291, 1031-1036, 2001.

Lihavainen, H., Kerminen, V.-M., Komppula, M., Hatakka, J., Aaltonen, V., Kulmala, M., and Viisanen, Y.: Production of "potential" cloud condensation nuclei associated with atmospheric new-particle formation in northern Finland, J. Geophys. Res., 108(D24), 4782, doi:10.1029/2003JD003887, 2003.

Liu, J., Mauzerall, D. L., and Horowitz, L. W.: Evaluating intercontinental transport of fine aerosols: (2) Global health impact, Atmos. Environ., 43, 4339-4347, 2009.

Lovejoy, E. R., Curtius, J., and Froyd, K. D.: Atmospheric ioninduced nucleation of sulphuric acid and water, J. Geophys. Res., 109, D08204, doi:10.1029/2003JD004460, 2004.

Mäkelä, J. M., Dal Maso M., Pirjola L., Keronen P., Laakso L., Kul- mala M. and Laaksonen A.. Characteristics of the atmospheric particle formation events observed at a boreal forest site in southern Finland, Boreal Environ. Res., 5, 299-313 2000.

Makkonen, R., Asmi, A., Korhonen, H., Kokkola, H., Järvenoja, S., Räisänen, P., Lehtinen, K. E. J., Laaksonen, A., Kerminen, V.M., Järvinen, H., Lohmann, U., Bennartz, R., Feichter, J., and Kulmala, M.: Sensitivity of aerosol concentrations and cloud properties to nucleation and secondary organic distribution in ECHAM5-HAM global circulation model, Atmos. Chem. Phys., 9, 1747-1766, doi:10.5194/acp-9-1747-2009, 2009.

Manninen, H. E., Nieminen, T., Asmi, E., Gagné, S., Häkkinen, S., Lehtipalo, K., Aalto, P., Vana, M., Mirme, A., Mirme, S., Hõrrak, U., Plass-Dülmer, C., Stange, G., Kiss, G., Hoffer, A., Törö, N., Moerman, M., Henzing, B., de Leeuw, G., Brinkenberg, M., Kouvarakis, G. N., Bougiatioti, A., Mihalopoulos, N., O’Dowd, C., Ceburnis, D., Arneth, A., Svenningsson, B., Swietlicki, E., Tarozzi, L., Decesari, S., Facchini, M. C., Birmili, W., Sonntag, A., Wiedensohler, A., Boulon, J., Sellegri, K., P. Laj, P., Gysel M., Bukowiecki, N., Weingartner, E., Wehrle, G., Laaksonen, A., Hamed, A., J. Joutsensaari, J., Petäjä, T., Kerminen, V.-M., and Kulmala, M.: EUCAARI ion spectrometer measurements at 12 European sites - analysis of new particle formation events, Atmos. Chem. Phys., 10, 7907-7927, doi:10.5194/acp10-7907-2010, 2010.

Merikanto, J., Spracklen, D. V., Mann, G. W., Pickering, S. J., and Carslaw, K. S.: Impact of nucleation on global CCN, Atmos. Chem. Phys., 9, 8601-8616, doi:10.5194/acp-9-8601-2009, 2009.

Merikanto, J., Spracklen, C. V., Pringle, K. J., and Carslaw, K. S.: Effects of boundary layer particle formation on cloud droplet number and changes in cloud albedo from 1850 to 2000, Atmos. Chem. Phys., 10, 695-705, doi:10.5194/acp-10-695-2010, 2010

Metzger, A., Verheggen, B., Dommen, J., Duplissy, J., Prevot, A. S. H., Weingartner, E., Riipinen, I., Kulmala, M., Spracklen, D. V., Carslaw, K. S., and Baltensperger, U.: Evidence for the role of organics in aerosol particle formation under atmospheric conditions, PNAS, 107(15), 6646-6651, 2010.

Nakajima, T., Sekiguchi, M., Takemura, T., Uno, I., Higurashi, A., Kim, D., Sohn, B. J., Oh, S.-N., Nakajima, T. Y., Ohta, S., Okada, I., Takamura, T. and Kawamoto, K.: Significance of direct and indirect radiative forcings of aerosols in the East China Sea region, J. Geophys. Res., 108(D23), 8658, doi:10.1029/2002JD003261, 2003.

Nakajima, T., Yoon, S.-C., Ramanathan, V., Shi, G.-Y., Takemura, T., Higurashi, A., Takamura, T., Aoki, K., Sohn, B.-J., Kim, S.-W., Tsuruta, H., Sugimoto, N., Shimizu, A., Tanimoto, H., Sawa, Y., Lin, N.-H., Lee, C.-T., Goto, D., and Schutgens, N.: Overview of the atmospheric Brown Cloud East Asian Regional Experiment 2005 and a study of the aerosol direct radiative forcing in east Asia, J. Geophys. Res., 112, D24S91, doi:10.1029/2007JD009009, 2007.

Nishita, C., Osada, K., Kido, M., Matsunaga, K., and Iwasaka, Y.: Nucleation mode particles in upslope valley winds at Mount Norikura, Japan: Implications for the vertical extent of new particle formation events in the lower troposphere, J. Geophys. Res., 113, D06202, doi:10.1029/2007JD009302, 2008.

Pandey, J. S., Kumar, R. and Devotta, S.: Health risks of $\mathrm{NO}_{2}, \mathrm{SPM}$ and $\mathrm{SO}_{2}$ in Delhi (India), Atmos. Environ., 39, 6868-6874, 2005.

Pant, P., Hegde, P., Dumka, U. C., Sagar, R., Satheesh, S. K., Moor- 
thy, K. K., Saha, A. and Srivastava, M. K.: Aerosol characteristics at a highaltitude location in central Himalayas: Optical properties and radiative forcing, J. Geophys. Res., 111, D17206, doi:10.1029/2005JD006768, 2006.

Raatikainen, T., Hyvärinen, A.-P., Hatakka, J., Panwar, T. S., Hooda, R. K., Sharma, V. P., and Lihavainen, H.: Comparison of aerosol properties from the Indian Himalayas and the Indo-Gangetic plains, Atmos. Chem. Phys. Discuss., 11, 1141711453, doi:10.5194/acpd-11-11417-2011, 2011.

Ramanathan, V., Crutzen, P. J., Lelieveld, J., Mitra, A. P., Althausen, D., Andersons, J., Andreae, M. O., Cantrell, W., Cass, G. R., Chung, C. E., Clarke, A. D., Coakley, J. A., Collins, W. D., Conant, W. C., Dulac, F., Heintzenberg, J., Heymsfield, A. J., Holben, B., Howell, S., Hudson, J., Jayaraman, A., Kiehl, J. T., Krishnamurti, T. N., Lubin, D., McFarquhar, G., Novakov, T., Ogren, J. A., Podgorny, I. A., Prather, K., Priestley, K., Prospero, J. M., Quinn, P. K., Rajeev, K., Rasch, P., Rupert, S., Sadourny, R., Satheesh, S. K., Shaw, G. E., Sheridan, P., and Valero, F. P. J.: Indian Ocean Experiment: An integrated analysis of the climate forcing and effects of the great Indo-Asian haze, J. Geophys. Res., 106(D22), 28371-28398, 2001.

Ramanathan, V., Li, F., Ramana, M. V., Praveen, P. S., Kim, D., Corrigan, C. E., Nguyen, H., Stone, E. A., Schauer, J. J., Carmichael, G. R., Adhikary, B., Yoon, S. C.: Atmospheric brown clouds: Hemispherical and regional variations inlongrange transport, absorption, and radiative forcing, J. Geophys. Res., 112, D22S21, doi:10.1029/2006JD008124, 2007a.

Ramanathan, V., Ramana, M. V., Roberts, G., Kim, D., Corrigan, C., Chung, C. and Winker, D.: Warming trends in Asia amplified by brown cloud solar absorption, Nature 448, 575-578, doi:10.1038/nature06019, 2007b.

Sagar, R., Kumar, B., and Dumka, U. C.: Characteristics of aerosol spectral optical depths over Manora Peak: A high-altitude station in the central Himalayas, J. Geophys. Res., 109, D06207, doi:10.1029/2003JD003954, 2004.

Sipilä, M., Berndt, T., Petäjä, T., Brus, D., Vanhanen, J., Stratmann, F., Patokoski, J., Mauldin III, Roy L., Hyvärinen, A.-P., Lihavainen, H. and Kulmala, M.: The role of sulphuric acid in atmospheric nucleation, Science, 327, 1243-1246, 2010.

Spracklen, D. V., Carslaw, K. S., Kulmala, M., Kerminen, V.-M., Mann, G. W., and Sihto, S. L.: The contribution of boundary layer nucleation events to total particle concentration on regional and global scales, Atmos. Chem. Phys., 6, 5631-5648, doi:10.5194/acp-6-5631-2006, 2006.

Spracklen, D. V., Mickley, L. J., Logan, J. A., Hudman, R. C., Yevich, R., Flannigan, M. D., and Westerling, A. L.: Impacts of climate change from 2000 to 2050 on wildfire activity and carbonaceous aerosol concentrations in the western United States, J. Geophys. Res., 114, D20301, doi:10.1029/2008JD010966, 2009.

Stohl, A., Wotawa, G., Seiberg, P., and Kromp-Kolb, H.: Interpolation errors in wind fields as a function of spatial and temporal resolution and their impact on different types of kinematic trajectories. J. Appl. Meteorol., 34, 2149-2165, 1994.

Takami, A., Miyoshi, T., Shimono, A., Kaneyasu, N., Kato, S., Kajii, Y., and Hatakeyama, S.: Transport of anthropogenic aerosols from Asia and subsequent chemical transformation, J. Geophys. Res., 112, D22S31, doi:10.1029/2006JD008120, 2007.
Twohy, C. H., Clement, C. F., Gandrud, B. W., Weinheimer, A. J., Campos, T. L., Baumgardner, D., Brune, W. H., Faloona, I., Sachse, G. W., Vay, S. A., and Tan, D.: Deep convection as a source of new particles in the midlatitude upper troposphere. J. of Geophys. Res. D, 107(D21), 4560, doi:10.1029/2001JD000323, 2002.

Venzac, H., Sellegri, K., Laj, P., Villani, P., Bonasoni, P., Marinoni, A., Cristofanelli, P., Calzolari, F., Fuzzi, S., Decesari, S., Facchini, M.-C., Vuillermoz, E., and Verza, G. P.: High Frequency New Particle Formation in the Himalayas, PNAS, 105(41), 15666-15671, 2008.

Venzac, H., Sellegri, K., Villani, P., Picard, D. and La, P.: Seasonal variation of aerosol size distributions in the free troposphere and residual layer at the Puy de Dôme station, France, Atmos. Chem. Phys., 9, 1465-1478, doi:10.5194/acp-9-1465-2009, 2009.

Wake, C. P., Dibb, J. E., Mayewski, P. A., Zhongqin, L., and Zichu, $\mathrm{X}$. : The chemical composition of aerosols over the Eastern Himalayas and Tibetan plateau during low dust periods, Atmos. Environ., 28, 4, 695-704, 1994.

Weber, R. J., Chen, G., Davis, D. D., Mauldin III, R. L., Tanner, D. J., Eisele, F. L., Clarke, A. D., Thornton, D. C., and Bandy, A. R.: Measurements on enhanced $\mathrm{H}_{2} \mathrm{SO}_{4}$ and 3-4 nm particles near a frontal cloud during the first aerosol characterization experiment (ACE 1), J. Geophys. Res. D, 106, 24107-24117, 2001 b.

Wiedensohler, A.: An approximation of the bipolar charge distribution for the particles in the submicron size range, J. Aerosol. Sci., 19, 387-389, 1988.

Winkler, P. M., Steiner, G., Vrtala, A., Vehkamäki, H., Noppel, M., Lehtinen, K. E. J., Reischl, G. P., Wagner, P. E., and Kulmala, M.: Heterogeneous Nucleation Experiments Bridging the Scale from Molecular Ion Clusters to Nanoparticles, Science, 319, 5868, 1374-1377, 2008.

Winklmayr, W., Reischl, G. P., Linder, A. O. and Berner, A.: A new electromobility spectrometer for the measurement of aerosol size distributions in the size range 1 to $1000 \mathrm{~nm}$. J. Aerosol. Sci., 22, 289-296, 1991.

Xu, B., Cao, J., Hansen, J., Yao, T., Joswia, D. R., Wang, N., Wu, G., Wang, M., Zhao, H., Yang, W., Liu, X., and He, J.: Black soot and the survival of Tibetan glaciers, PNAS, 106, 52, 22114 22118, 2009.

Yu, F. and G. Luo: Simulation of particle size distribution with a global aerosol model: contribution of nucleation to aerosol and CCN number concentrations, Atmos. Chem. Phys., 9, 76917710, doi:10.5194/acp-9-7691-2009, 2009.

Zhang, Y., Li, T., and Wang, B.: Decadal Change of the Spring Snow Depth over the Tibetan Plateau: The Associated Circulation and Influence on the East Asian Summer Monsoon, J. Climate, 17, 2780-2793, 2003.

Zhang, M., Song, Y., and Cai, X.: A health-based assessment of particulate air pollution in urban areas of Beijing in 2000-2004, Sci. Total Environ., 376, 100-108, 2007. 